\title{
Study to compare de-epithelized inner preputial skin flap and Dartos fascia flap as water-proofing layer in hypospadias repair by Snodgrass' Technique
}

\author{
Puneet Kumar $^{1}$, Sudhir Kumar ${ }^{2, *}$, Manish Jain ${ }^{3}$, Brijendra Singh ${ }^{4}$ \\ ${ }^{1}$ Senior Resident, ${ }^{2}$ Professor, ${ }^{3}$ Associate Professor, ${ }^{4}$ Professor, Dept. of Surgery, ${ }^{\mathbf{1 , 2 , 3}}$ MLB Medical College Jhansi, \\ ${ }^{4}$ All India Institute of Medical Sciences, Rishikesh, India \\ *Corresponding Author: \\ Email: sudhirplastic@yahoo.co.in
}

\begin{abstract}
We conducted a study to compare two different methods of water proofing in hypospadias repair. All 30 cases in our study were repaired by using Snodgrass technique. In 15 cases water proofing was done using inner preputial de-epithelialized skin flap. This group was named as group A in our study. In another group Dartos fascia was used as water proofing layer. This group was named Group B in this study. The minimum period of follow-up in this series was 18 months.

In Group A: One patient had fistula which healed spontaneously. One patient had partial wound dehiscence that resolved on conservative measures. Skin necrosis, meatal stenosis, stricture of neourethra and residual chordee was not seen in this group. One case required catheter removal on $3^{\text {rd }}$ day because of severe bladder spasm.

In Group B: Urethrocutaneous fistulae were seen in two cases. One healed by itself but one persisted. Skin necrosis occurred in two cases. One healed spontaneously but in other we have to cover it with scrotum (CecilCulp Procedure) to salvage the repair. Meatal stenosis, urethral stricture and residual chordee were not seen in any patient.

We conclude that inner preputial de- epithelialized skin flap may have an edge over Dartos fascia for coverage of the neourethra as water proofing layer.
\end{abstract}

Received: $06^{\text {th }}$ June, 2017

Accepted: $13^{\text {th }}$ January, 2018

\section{Introduction}

The most troublesome complication of hypospadias surgery is fistula formation which usually requires re-operation. To lessen the incidence of urethrocutaneous fistulae vascularized soft tissue layer is interposed between neourethra and skin cover. Tissues like Dartos fascia, corpus spongiosum, tunica vaginalis and de-epithelised inner preputial skin has been used as water-proofing layers.

Remnants of spongiosum are usually inadequate for satisfactory coverage. Moreover very careful dissection is required to raise it.

Tunica vaginalis supplies abundant tissue for water-proofing but requires exploration of scrotum.

Anatomical basis for harvesting Dartos fascia and de-epithelized inner preputial skin flap is dual blood supply to penis. Deep structures of penis are supplied by branches from internal pudendal arteries while Dartos and penile skin is perfused by external pudendal vessels (Fig. 1). This anatomical fact permits surgeon to play freely with these tissues.

Both Dartos fascia and de-epithelialized inner preputial skin flap provide robust cover to the urethra and act as a barrier between the suture lines. Dartos fascia is harvested from the dorsal penile skin, is more frequently used. Harvesting Dartos fascia may be difficult for beginners as it requires precise and skilful dissection to raise the Dartos flap without damaging the intrinsic blood supply to the outer skin. Any damage to

vasculature of skin will lead to skin necrosis jeopardizing repair.

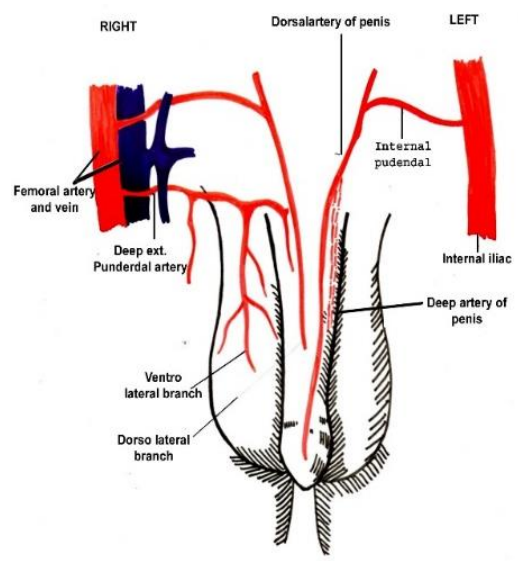

Fig. 1: Blood supply to penis. Deep structures are supplied by internal Pudendal vessels while skin and Dartos fascia are perfused by ext Pudendal vessels 
De-epithelialized inner preputial skin flap was described by Durham Smith in 1973. Inner layer of prepuce is de-epithelized and it is raised as a flap based on Dartos fascia. Then it is laid over the suture line of neourethra reconstructed by tubularisation of incised urethral plate. Dermis is secured in place by few tucking sutures. This is robust tissue in comparison to Dartos fascia alone and holds sutures better. As dermal pedal adds to the length of flap less amount of dissection is needed so there are less chances of skin necrosis. The choice between the two depends more on surgeon's choice and experience rather than scientific evidence.

Aim of present study is to compare these two methods of water-proofing

\section{Material and Methods}

It is study of total 30 cases of hypospadias without or with minimal chordee operated at our institute over a period of 18 months (January 2015 to JUNE 2016).

Mean age of patients in our study group was 4 years. Meatal position was subcoronal in 16, distal penile in 12 and mid penile in 2 patients. Patients with good preputial hood, absent or minimal chordee and well formed urethral plate ( $>5 \mathrm{~mm}$ in width) were included in study group. The patients with severe chordee and inadequate urethral plate were excluded.

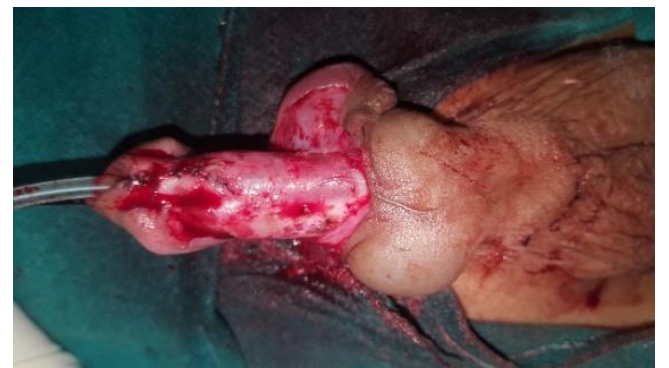

Fig 2: After tubularization of incised urethral plate

All these cases were operated by tubularization of incised plate or commonly known as Snodgrass technique (Fig. 2). After urethroplasty either Dartos fascia or deepithelized inner preputial skin flap based on Dartos fascia was used as water-proofing layer. Dartos fascia and inner preputial skin flap was used on alternate patient.

So de-epithelised inner prepuce skin flap was used in 15 cases (Group A) and in rest 15 cases dorsal dartos fascia was used (Group B).

Before harvesting inner layer of prepuce, it was de-epithelized using number 23 surgical blade. Island of skin to be de-epithelised was held with 4 stay sutures (Fig. 3). This dermal pedal was raised as flap pedicled over Dartos fascia.

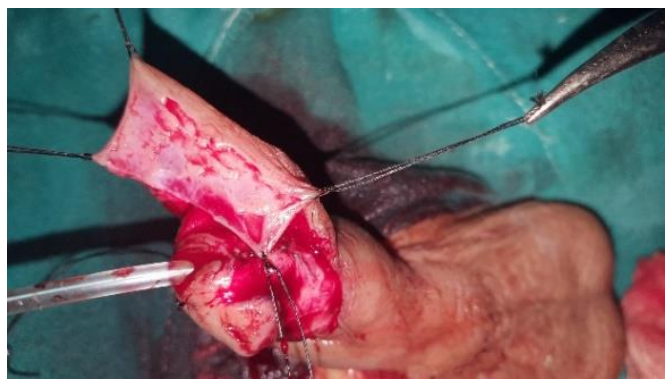

Fig 3: De-epithelization of inner preputial skin

Dartos fascia was gently harvested with scissors taking care to preserve the blood supply to overlying skin.

Water-proofing layer was laid over the suture line of urethroplasty and anchored in place by few 5-0 Vicryl stitches (Fig 4). Skin cover was done by Bayar's method. First check dressings were done on day 5 (Fig 5). Catheter was removed after 10 days of repair.

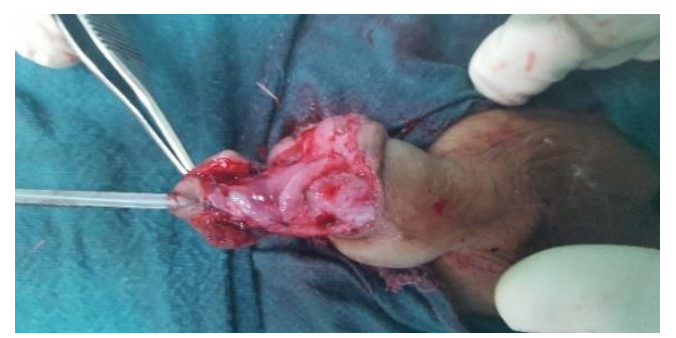

Fig. 4: De-epithelized flap placed over suture line of neo-urethra and anchored with 5-0 Vicryl stitches

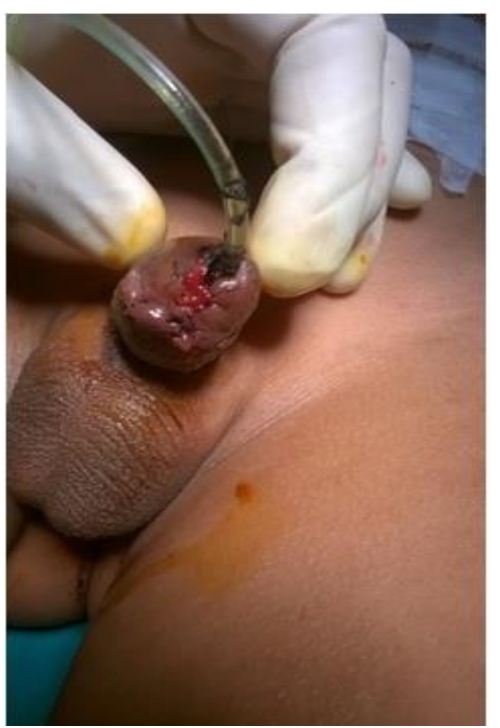

Fig. 5: First check dressing on post-operative day 5 
Patients were called for follow-up every week for two weeks then after one month. After this patients were called for follow up at three months and one year. The minimum period of follow-up in this series was of three months.

\section{Results}

1. The most common age group was 1-4 years followed by 4-6 years with average age of 4 years. Meatal position was subcoronal in 16, distal penile in 12 and mid penile in 2 patients.
2. Post-operative aesthetics were satisfactory in both groups. New reconstructed meatus was located at glans tip, slit like, vertically oriented and normal looking. Glans shape was normal. Scar of midline stitch line gives illusion of central raphae on central aspect.

3. Both water-proofing procedures are easy to perform, provides adequate tissue and harvest tissue from primary operative site. Harvesting of de-epithelized dermal flap takes more time (average 20 minutes in comparison 10 minutes) than for Dartos fascia.

Table 1

\begin{tabular}{|l|c|c|}
\hline \multicolumn{1}{|c|}{ Complications } & Group a (n=15) & Group b(n=15) \\
\hline Meatal Stenosis & 0 & 0 \\
\hline Fistula requiring closure & One & One \\
\hline Glans dehiscence & Partial(superficial) & None \\
\hline Fistula healing spontaneusly & One & One \\
\hline Residual chordee & None & None \\
\hline Gross Torsion(>30 degrees) & None & $\begin{array}{c}2 \\
\text { Skin necrosis }\end{array}$ \\
\hline None & $\begin{array}{c}\text { 1 managed conservatively } \\
\text { needed surgical intervention }\end{array}$ \\
\hline $\begin{array}{l}\text { Average time to Harvest } \\
\text { water-proofing layer }\end{array}$ & 20 minutes & 10 minutes \\
\hline Catheter related problems & 1 & None \\
\hline
\end{tabular}

\section{Discussion}

Surgical techniques for the repair of hypospadias are being developed continuously, implying that no single technique is considered as perfect for hypospadias.

Snodgrass' technique of tubularized incised plate urethroplasty uses uretral plate for reconstruction of urethra. This is best tissue for urethroplasty. As urethral plate is firmly adherent to deeper tissues urethral diverticulla are not seen after this repair. Aesthetic results of this repair are very good as normally placed slit like, vertically oriented and a cosmetically normal neomeatus constructed.. The key step in the procedure is to divide the urethral plate by deep sagital incision in the midline, dividing all transverse webs, and exposing the underlying corporal bodies. This allows for its subsequent tubularization. Initially Snodgrass reported tubularized incised plate urethroplasty for distal hypospadias where no fistula was reported. Later on, he reported multicentric experience of tubularized incised urethroplasty (148 patients). Complications were reported in 10 patients (7\%).
Water-proofing procedures are effective in decreasing the fistula rates. They provide an extra tissue layer between stitch line of neourethra and skin cover of penis. This layer carries additional vascularity with it and helps in healing. Variety of tissues are used for waterproofing in various hypospadias repair.

Durham Smith described de-epithelialized overlap flap in 1973. He used this technique in two-stage procedures and reported only one fistula in 51 patients (2\%). Other features of his repair included a urethral tube of uniform lumen, an orifice on tip of the glans and a cosmetic appearance of a normal circumcised male. The only limitation of Smith's procedure was that it was applied exclusively to a two-stage procedure. With experience, it became apparent that de-epithelialized flap is also helpful in the successful closure of urethrocutaneous fistula.

Snow et al. in 1995 reported first time the use of tunica vaginalis to interpose between reconstructed urethra and dartos and skin. The fistula rate reported was $9 \%$. Similar results have been reported by Shanker et al. and Handoo. It has a dependable blood supply from the cremasteric vessels and its pedicle length can safely be increased up to the external inguinal 
ring. Main drawback of this technique is that it requires exploration of scrotum.

Sozibur and Snodgrass used a dorsal Dartos pedicle flap obtained from the dorsal prepuce, buttonholed and transposed to the ventrum for additional covering of the neurethra. However, they reported complications in $14 \%$ of patients.

Djordjevic ML et al in 2005 showed a dorsal well-vascularized dartos flap, buttonholed ventrally, to be a good choice for preventing fistula. Redundancy of the flap and its excellent vascularization depends on the harvesting technique.

Dorsal Dartos flap though is locally available but inadvertent dissection results in necrosis of the overlying skin due to compromising its blood supply but still provides a good cover to the neo urethra.

\section{Conclusions}

De-epithelialised flap is a simple method to provide additional cover to the constructed neourethra after Snodgrass urethroplasty. It is more effective than simple dartos flap in preventing uretrocutaneous. Incidence of skin necrosis is less with de-epithelised flap but it requires more operating time. As sample size in this study is small further studies are recommended.

\section{References}

1. Smith DA. de-epithelialised overlap flap technique in the repair of hypospadias. Br J Plast Surg 1973 Apr;26(2):106-14.

2. Durham S. A de-epthelialized overlap flap technique in the repair of hypospadias. Br J Plast Surg 1973;26:106-14.

3. Snodgrass W. Tubularized incised plate urethroplasty in distal hypospadias. J Urol 1994;151:464-5.

4. Snodgrass W, Koyle M, Manjoni G. Tubularized incised plate hypospadias repair: Results of a multicentric experience. J Urol 1996;156:839-41.

5. Berry BA. De-epithelialized skin flap cover in hypospadias repair. J Urol 1988;140:1273-6.

6. Ross JH, Kay R. Use of de-epithelialized local skin flap in hypospadias repairs accomplished by tubularization of the incised urethral plate. Urology 1997;50:110-2.

7. Snow BW, Cartwright PC, Unger K. Tunica vaginalis blanket wrap to prevent urethracutaneous fistulas an eight year experience. J Urol 1995; 153:472-3.

8. Shanker KR, Losty PD, Hopper M, Wong L, Rickwood AM. Outcome of hypospadias fistula repair. BJU Int 2002;89:103-5.

9. Handoo YR. Role of tunica vaginalis interposition layer in hypospadias surgery. Indian J Plast Surg 2006;39:152-6.
10. Snodgrass WT. Assessing outcome of Hypospadias surgery. J Urol 2005;174:816-7.

11. Djordjevic ML, Provic SV, Slakovic Z, Djakovic N. Longitudinal dorsal dartos flap for prevention of fistula after Snodgrass hypospadias procedure. Eur Urol. 2006;50:53-57. 